\title{
THE POLICING OF MAJOR EVENTS IN CANADA: LESSONS FROM TORONTO'S G20 AND VANCOUVER'S OLYMPICS
}

\author{
W. Wesley Pue \\ Robert Diab \\ Grace Jackson*
}

Major events ranging from sporting events to major international conferences too often result in disorder, deployment of riot squads, and mass arrests. Events surrounding a meeting of the G20 in Toronto and those at Vancouver's Winter Olympics provide insight into the ways in which things can go wrong and the ways in which they can go well at major events. This article employs a "thick history" of events in order to explore gaps in Canadian law, including gaps between "law in the books" and "law in action."

The legal frameworks governing large-scale events affect the likelihood of success measured in public safety, minimization of disorder, and protection of basic liberties. Surprisingly, large events often proceed without the benefit of a developed legal framework, leading to confusion among federal police, local police, and civil authority. We assess past reliance on the common law, a Vancouver City bylaw, Ontario's Public Works Protection Act [PWPA], and the policing and security provisions of the federal Foreign Missions and International Organizations Act (Foreign Missions Act) in order to determine which sorts of legal arrangements are most conducive to successful event management. Since major events in Canada are most often developed in law's penumbra, without the benefit of clear legal authority or statutory direction governing the measures that are required, both effective management and ordinary liberties are compromised. A "worst of both worlds" outcome destabilizes police-citizen relationships and leaves individuals uncertain as to the durability of their rights of property, speech, assembly, movement, and personal integrity. Equally, police forces are left insecure as to the lawful means by which they should perform their duties. A comparison of the two events provides the pathology and a prescription, illustrating the need for legislation to govern the management of major events.

Trop souvent, la tenue de grands événements, comme les événements sportifs ou les grandes conférences internationales, mène au chaos, au déploiement d'escouades anti-émeute et à des arrestations massives. Un retour sur les événements entourant la tenue d'un sommet du G20 à Toronto et des Jeux olympiques d'hiver de Vancouver nous donne un aperçu des choses qui peuvent bien fonctionner et des dérapages possibles à ces occasions. Dans le présent

* W. Wesley Pue, Faculty of Law, University of British Columbia; Robert Diab, Faculty of Law, Thompson Rivers University; and Grace Jackson, Barrister and Solicitor. We are grateful to the anonymous referees for their thoughtful comments and suggestions for refining this article. 
article, nous passons en revue ces événements afin d'explorer les lacunes que comporte le droit canadien, y compris les écarts entre le droit théorique et le droit pratique.

Les paramètres juridiques qui régissent les événements de grande envergure influent sur l'efficacité des mesures liées à la sécurité publique, à la restriction des risques de chaos et à la protection des libertés fondamentales. Fait étonnant, les grands événements se déroulent souvent sans qu'un cadre juridique ait été mis au point, ce qui mène à la confusion entre les autorités policières fédérales et locales et les autorités civiles. Nous nous penchons tour à tour sur l'application passée des règles de common law, d'un règlement de la ville de Vancouver, de la Loi sur la protection des ouvrages publics de l'Ontario et des dispositions relatives à la surveillance policière et à la sécurité de la Loi sur les missions étrangères et les organisations internationales (loi fédérale) afin de déterminer les types de mesures juridiques les plus susceptibles d'assurer une gestion réussie des événements. Étant donné que les grands événements tenus au Canada sont planifiés le plus souvent dans la pénombre du droit, en l'absence d'une autorisation juridique ou de directives législatives claires régissant les mesures qui sont nécessaires, tant la gestion efficace que les libertés ordinaires sont compromises. Lorsque la situation dégénère et que le pire survient, les relations entre la police et les citoyens sont déstabilisées et les individus s'interrogent sur la durabilité de leurs droits de propriété ainsi que de leurs droits de s'exprimer, de se rassembler, de se déplacer et de protéger leur intégrité personnelle. De leur côté, les forces policières ont des doutes sur les moyens légaux auxquels elles peuvent recourir pour exercer leurs fonctions.

Nous comparons les deux événements afin de présenter la pathologie et une prescription mettant en lumière la nécessité d'adopter un texte législatif régissant la gestion des grands événements.

\section{INTRODUCTION}

Recent reviews of policing at Toronto's G20 Summit and Vancouver's Olympics provide unprecedented insight into the law and practice of large event policing in Canada. ${ }^{1}$ These two

\footnotetext{
See Margaret Beare \& Nathalie Des Rosiers, eds, Putting the State on Trial: The Policing of Protest during the G20 Summit (Vancouver: University of British Columbia Press, 2015); Gerry McNeilly, Office of the Independent Police Review Director, Policing the Right to Protest: G20 Systemic Review Report (Toronto: Office of the Independent Police Review Director, 2012) [OIPRD Report]; Ian McPhail, Civilian Review and Complaints Commission for the RCMP, Public Interest Investigation into RCMP Member Conduct Related to the 2010 G8 and G20 Summits (Ottawa: Commission for Public Complaints against the RCMP, 2012) [CPC Report]; John W Morden, Toronto Police Services Board, Independent Civilian Review into Matters Relating to the G20 Summit (Toronto: Toronto Police Services Board, 2012) [TPSB Review]; André Marin, Ombudsman, Caught in the Act: Investigation into the Ministry of Community Safety and Correctional Services' Conduct in Relation to Ontario Regulation 233/10 under the Public Works Protection Act (Toronto: Ombudsman Ontario, 2010) [Ombudsman's Report]; Ontario Special Investigations Unit, "SIU Concludes Six Investigations into
} 
enormous events were held 4,000 kilometres apart in the same year. Different in character and managed under contrasting legal frameworks, they provide a natural experiment of sorts through which to assess the legal conditions most conducive to success. Taken together, they offer unique visibility into the legal and operational environments that shape law's practical outcomes, providing new insights into the way Canada's laws are understood and applied by the officials charged with their application and how that in turn affects the likelihood of successful event management.

We approach the material and the problem through a form of socio-legal enquiry, engaging a "thick history" of events in order to more fully understand the interaction of law and outcomes in the choreographies of large events. ${ }^{2}$ We approach "law" through judicial decisions, statutes, and regulations but also as a living reality shaped and applied by officials. In seeking to understand how and to what extent law conditions action, we probe the "gaps" between the law as written, the law as understood by the officials charged with implementing it, and the law that lies between these two forms and the actual outcomes. ${ }^{3}$ We use official records to excavate "law in action." 4

Specifically, the assessment of the two events offers new insights into the ways in which the common law, a municipal bylaw, a provincial statute, and the policing and security provisions of

Injuries during the G20 Summit," News Release 10-TCI-118 (25 November 2010), online:

$<$ http://www.siu.on.ca>; Ontario Special Investigations Unit, "Toronto Police Service Police Officer Charged,"

News Release 10-TCI-118 (21 December 2010), online: <http://www.siu.on.ca>; House of Commons, Standing Committee on Public Safety and National Security, "Issues Surrounding Security at the G8 and G20 Summits: Report of the Standing Committee on Public Safety and National Security" (March 2011) (Chair: Kevin Sorenson); National Union of Public and General Employees and Canadian Civil Liberties Association, "Breach of the Peace, G20 Summit: Accountability in Policing and Governance" (Ottawa, 2011) ["Breach of the Peace"]; Ontario Provincial Police (OPP), "Consolidated after Action Report: Muskoka G8 Summit 2010 Toronto G20 Summit" (2011); R Roy McMurtry, Ministry of Community Safety and Correctional Services, Report of the Review of the Public Works Protection Act (Toronto: Ministry of Community Safety and Correctional Services, 2001); Adam Molnar \& Lauren Snider, "Mega-Events, Mega-Profits: Unpacking the Vancouver 2010 Security-Development Nexus" in Colin J Bennett \& Kevin D Haggerty, eds, Security Games: Surveillance and Control at Mega-Events (New York: Routledge, 2011) 150; Canada, Royal Canadian Mounted Police, "Games Security and Public Safety for the Vancouver 2010 Olympic and Paralympic Games," online: $<$ http://www.rcmp-grc.gc.ca/aud-ver/reports-rapports/pp-gs-ps-eval-eng.htm>.

2 Clifford Geertz, "Thick Description: Toward an Interpretive Theory of Culture" in The Interpretation of Cultures: Selected Essays (New York: Basic Books, 1973) 3.

3 As David Nelken has stated, "the effects of normative legal or administrative guidelines to behaviour could not be understood without reference to the way in which they were refracted by the social environment." David Nelken, "The 'Gap Problem' in the Sociology of Law: A Theoretical Review" (1981) 1 Windsor YB Access Just 35 at 43. See also David Nelken, Beyond Law in Context: Developing a Sociological Understanding of Law (London: Ashgate, 2009); Michael McCann emphasizes the centrality of the "gap problem" in socio-legal studies in Michael McCann, "2013 LSA Presidential Address: The Unbearable Lightness of Rights: On Sociolegal Inquiry in the Global Era" (2014) 48:2 Law \& Soc'y Review 245 at 246. See also Jon Gould \& Scott Barclay, "Mind the Gap: The Place of Gap Studies in Sociolegal Scholarship" (2012) 8 Ann Rev Law \& Soc Sci 323 at 323-335.

4 Roscoe Pound is generally credited with originating the approach to law and society research that focuses on the actual effects of legal rules rather than only on their assumed rationale and effect. See Roscoe Pound, "Law in Books and Law in Action" (1910) 44 Am L Rev 12. 
the federal Foreign Missions Act interact. ${ }^{5}$ In exploring each of these in the context of real events, unfortunate lacunae in the legal framework become apparent. Gaps arise from the false assumption that event management is co-extensive with security planning, from confusion over the boundaries between federal and provincial authority to the failure of any level of government in Canada to establish a comprehensive legal framework for the management of large events.

\section{BACKGROUND}

Toronto's 2010 G20 Summit and associated meetings of the G8 in nearby Huntsville constituted one of the "largest domestic security operations in Canadian history." Although delegates were protected and meetings proceeded more or less uninterrupted, things did not go well. Widespread disorder played out on the streets of Toronto. On one occasion, an organized group of troublemakers engaged in a rampage of vandalism, while police did nothing. Property was destroyed, and members of the public were frightened. ${ }^{7}$ On other occasions, law-abiding individuals were interfered with, attacked, confined, detained, or otherwise abused by police. ${ }^{8}$ Over 1,000 people were arrested, often held under deplorable conditions, without legal justification. James Stribopoulos observes that of the 1,105 individuals arrested, only 321 were charged, of whom 204 had charges "stayed, withdrawn or dismissed. In short, nearly 90 percent of those arrested ... were quite possibly innocent of any wrongdoing."

Police forces struggled to plan for and manage the G20 events on short notice and unworkable time frames. ${ }^{10}$ An inadequate legal framework contributed significantly to the difficulties. In all of this upheaval, the G20/G8 was dramatic but, sadly, not uncommon. Canada does not have a

5 City of Vancouver, Bylaw no 9962 on Vancouver 2010 Olympic and Paralympic Winter Games (3 December 2009) [Bylaw 9962]; Public Works Protection Act, RSO 1990, c P.55, as repealed by Security for Electricity Generating Facilities and Nuclear Facilities Act, 2014, SO 2014, c 15, Schedule 1, s 1 [PWPA]; Foreign Missions and International Organizations Act, SC 2002, c 12, s 10.1 [Foreign Missions Act].

6 OIPRD Report, supra note 1 at iii.

7 Scholarship and official reports emerging in the aftermath of the events document this extensively as did news coverage. Examples of news coverage include: Christie Blatchford, "Black Bloc Interrupted Soldier's Cortège: Blair", Globe and Mail (1 July 2010), online: <www.theglobeandmail.com>; Postmedia News, "Ottawa Agrees to Pay Businesses Nearly \$2M in G8/G20 Compensation”, National Post (15 June 2011), online:

$<$ www.nationalpost.com $>$.

8 Kelly Grant, "Police Chief Offers No Apologies for G20 Tactics", Globe and Mail (28 June 2010), online: $<$ www.theglobeandmail.com $>$.

9 James Stribopoulos, "The Rule of Law on Trial: Police Powers, Public Protest and the G20" in Beare \& Des Rosiers, supra note 1, 105 at 105-106. See also eg the arrest of 108 people on the early morning of 27 June as they awoke in a gymnasium at the University of Toronto and the "kettling incident" later the same day, in which police boxed in some 400 protesters and others at a downtown intersection confining them in place for four hours during a torrential rainfall (OIPRD Report, supra note 1 at 142-157). See also the criticism of the conditions and procedures for booking and detaining suspects at a temporary holding facility created for the event (OIPRD Report, supra note 1 at 200-242).

10 See eg the OIPRD Report, supra note 1; Beare \& Des Rosiers, supra note 1. 
good record when it comes to large event policing. ${ }^{11}$ The ways in which the Vancouver Olympics provide a useful counterpoint will be examined below.

\section{CANADIAN LAW OF LARGE EVENT POLICING}

One factor auguring against success is the surprising failure of Canada's legislatures to set out a legal framework for the management of large events. Common sense dictates that special arrangements need to be made wherever very large numbers gather. This is about more than policing protests. Authorities need the power to limit access to public space, restrict the freedom of movement, constrain the means and location of expression, and conduct searches of persons and property in a fashion that is not generally tolerable in a free society. Some measures are needed to ensure the security of an event as such. Others facilitate the exercise of the freedoms of movement, expression, protest, and assembly by ensuring the safety and convenience of people in the area, including demonstrators. All of this is routine at such events, though it is most often done without clear legal authority. ${ }^{12}$

Legal authority was bootstrapped into being for each of the 2010 events when that surprising fact was recognized by responsible officials. An aging and mostly forgotten statute was dusted off and secretly invoked for the Toronto events, while a city bylaw, enacted in full public view, served to bridge the void in Vancouver. ${ }^{13}$ As a result, the G20 meetings were plagued by

11 Investigations of the 1997 Asia-Pacific Economic Cooperation (APEC) conference in Vancouver provided useful guidance as to general principles but not as rich an insight into the ways in which operational and legal concerns jointly shaped policing. Previous discussions of large-event policing in Canada, including the APEC affair, include W Wesley Pue, ed, Pepper in Our Eyes: The APEC Affair (Vancouver: UBC Press, 2000) [Pue, Pepper in Our Eyes]; Robert Diab \& W Wesley Pue, "The Gap in Canadian Police Powers: Canada Needs 'Public Order Policing' Legislation" (2010) 28 Windsor Rev Legal Soc Issues 87 at 87-107 [Diab \& Pue, "The Gap in Canadian Police Powers"]; Robert Diab \& W Wesley Pue, "Security for the 2010 Olympics: The Gap in Police Powers under Canadian Law", The Advocate (September 2009); W Wesley Pue, "Trespass and Expressive Rights" (Ipperwash Inquiry, 2007) [Pue, "Trespass and Expressive Rights"]; Lorne Sossin, "The Oversight of Executive Police Relations in Canada: The Constitution, the Courts, Administrative Processes and Democratic Governance" (Ipperwash Inquiry, 2004); Margaret Beare and Tonita Murray, eds, Police and Government Relations: Who's Calling the Shots (Toronto: University of Toronto Press, 2007) at 131-134; W Wesley Pue, "The Prime Minister's Police? Commissioner Hughes' APEC report" (2001) 39:1 Osgoode Hall LJ 165 [Pue, "The Prime Minister's Police"]; W Wesley Pue, "Executive Accountability and the APEC Inquiry: Comment on 'Ruling on Applications to Call Additional Government Witnesses"” (2000) 34 UBC L Rev 335 [Pue, "Executive Accountability and the APEC Inquiry"]. In an important paper prepared for the Ipperwash Inquiry in 2004, Willem de Lint, "Public Order Policing in Canada: An Analysis of Operations in Recent High Stakes Events" (Ipperwash Inquiry, 2004) reviews large-event policing at Oka, Burnt Church, APEC (Vancouver), the Organization of American States (Windsor), the Summit of the Americas (Quebec City), and the G8 meetings held at Kananaskis.

12 A vague statutory provision incorporated in the Foreign Missions Act, supra note 5, granting the Royal Canadian Mounted Police (RCMP) authority over security at inter-governmental meetings does little to resolve the multifarious matters related to managing and policing such events (explored in more detail below). We leave aside the possibility of efforts to inhibit the exercise of these rights under the guise of "security" or "safety." Any such effort would be clearly unlawful, as Commissioner Hughes concluded in his report on policing at Vancouver's 1997 APEC conference. See Pue, "The Prime Minister's Police", ibid.

13 PWPA, supra note 5; Bylaw 9962, supra note 5. 
confusion despite Herculean efforts by civil servants and police. At the Olympics, in marked contrast, the bylaw established a framework for the regulation of public space, the movement of people, and crowd management. ${ }^{14}$ Officials enjoyed clarity as to both their mission and authority, and inter-agency confusion was minimal. Things went well.

\section{A. Limits of Authority for Public Order Policing in Canada}

The main statutory provision governing the policing of major international conferences is found in the Foreign Missions Act. No equivalent federal statute governs international sporting events, and there is no similar provision in provincial legislation. The policing portion of the Act is brief:

10.1 (1) The Royal Canadian Mounted Police has the primary responsibility to ensure the security for the proper functioning of any intergovernmental conference in which two or more states participate, that is attended by persons granted privileges and immunities under this Act and to which an order made or continued under this Act applies.

(2) For the purpose of carrying out its responsibility under subsection (1), the Royal Canadian Mounted Police may take appropriate measures, including controlling, limiting or prohibiting access to any area to the extent and in a manner that is reasonable in the circumstances. ${ }^{15}$

Subsection 3 clarifies that the Act is not intended to affect any statutory or common law powers of police, and subsection 4 allows for arrangements to be entered into between federal and provincial or municipal authorities. This is the full extent of the legislation.

We will have more to say about the ambiguities and gaps in this light-touch statutory framework later in this article. It sets out the authority of the federal police force in relation to the security and functioning of international governmental conferences. Other matters, even nearby and at the same time, are outside of its scope. Moreover, the restriction to intergovernmental conferences (federal jurisdiction) means that other occasions triggering large gatherings that are likely to significantly disrupt the ordinary ebb and flow of urban living are not covered. Many other commonplace events, such as summer festivals, firework displays, major sport competitions, celebratory gatherings, religious assemblies, demonstrations, protests, and labour unrest, also bring large numbers of people together in public spaces, where they are sometimes fired up by emotion or intoxicants or both. ${ }^{16}$ Any such occasion can threaten disorder. Sporting events such as the Olympics or Pan American Games are international in character,

14 The two cases differ in other critical respects. For the Winter Olympics, eg, a four-year lead time facilitated thorough preparation, allowed productive discussions with protest leaders, and permitted a more complete attention to police operations than was possible in the four months of preparation for the G20 Summit.

15 Foreign Missions Act, supra note 5.

16 See eg Commission for Public Complaints against the RCMP, "CPC Releases Investigation Report into the Search and Seizure of Alcohol by the Police in Victoria, BC on Canada Day 2008", News Release (27 March 2009), online: <www.newswire.ca $>$ (indicating "Police efforts to curb excessive alcohol consumption and rowdiness at civic celebrations may need municipal or provincial legislative support"). 
requiring a federal presence, but they are not conferences of the sort captured by the Foreign Missions Act's policing provisions.

Managing urban co-existence, while attending to the needs of very large crowds and facilitating safe movement and free expression has led police to refine their techniques over time. The modern repertoire includes fenced perimeters, designated "protest zones," and intrusive, atypical surveillance, search, or detention. The wisdom of taking some such measures is obvious. Properly calibrated and applied, all may be prudent in some circumstances. ${ }^{17}$ Outside of the "intergovernmental conference" context, however, the statutory or common law authority for most such measures is thin. ${ }^{18}$ Even in this one circumstance, a fuzzy boundary between provincial and federal jurisdiction confounds.

It is common to discuss all that takes place in making arrangements for major events under the rubric of "security" or the management of "protests" or "public order." Although this is the most common language employed by police and security officials, government spokespersons, and academic commentators, this language distorts understanding. It turns out that not everything that happens around an inter-governmental conference is connected directly to the meeting's security and functioning. Leaving aside protection from aerial, missile, or similar attacks important but beyond our scope ${ }^{19}-$ at least four different sorts of needs arise:

1. Security for the event itself: whether a major event is a hockey game in a sports arena or a meeting of international leaders at a conference facility, security must be provided for participants when they travel, eat, and sleep. Security for the event itself, for its immediate environs and access points, and for the delegates as they move to and fro must be assured.

2. The management of vehicle and pedestrian traffic: when unusually large numbers of people convene in public spaces such as roads, sidewalks,

17 Other features of large-event policing are troubling, though outside our scope. Lesley Wood identifies a disturbing catalogue in "Reorganizing Repression: Policing Protest 1995-2012" in Beare \& Des Rosiers, supra note 1, 44 at 57-58: "[I]t is not unusual to have pre-emptive raids of activist spaces, surveillance and infiltration, barricaded areas, large numbers of arrests, and less lethal weapons. There is an escalation in the frequency of the use of some militarized tactics, and the costs of providing security at such events. There is also some variation between the US and Canadian contexts. Mass arrests, and the subsequent class action lawsuits, are much more routine in the US, whereas, pepper spray, tear gas and TASERing of protesters more common in Canada. Despite these differences, however, a generalized approach has consolidated since 1999." (One could argue that the shift began, not in Seattle in 1999, but in Vancouver two years earlier; nonetheless, the evolution is there to be seen over something like this period).

18 Foreign Missions Act, supra note 5. The Quebec National Assembly's passage of Bill 78 in 2012 was only a partial and temporary exception in that the bill (which was in force for roughly two months) required that public protests involving ten or more persons be preceded by at least eight hours' notice to police of the "date, time, duration and venue of the demonstration as well as its route, if applicable." Bill 78, An Act to Enable Students to Receive Instruction from the Postsecondary Institutions They Attend, $2^{\text {nd }}$ Sess, $39^{\text {th }}$ Leg, Quebec, 2012, s 16. Kent Roach identifies the many "security" operations outside of the police that come into play at major international events. Other agencies include the Canadian Security Intelligence Service, the military, the Canadian Border Services Agency, the Communications Security Establishment Canada, and the Joint Intelligence Group. See Kent Roach, "Post 9/11 Policing of Protests: Symbolic but Illusionary Law Reform and Real Accountability Gaps" in Beare \& Des Rosiers, supra note 1, 64 at 64-83. 
thoroughfares, and pathways, normal modes of transportation and personal movement are disrupted. Sheer volume disrupts ordinary patterns of urban life. Minimizing public inconvenience requires careful forward planning that may involve limiting access to some public spaces. Further restrictions arising from the needs of event security or safe transportation for delegates compound the challenges respecting traffic flow. All of this inevitably has a secondary effect of constraining the time and manner of protests, though that is not properly the intent.

3. The facilitation of collective expression: The management of time and space where the right to exercise collective expression is engaged requires wisdom. It is important to strike an appropriate balance between the protection of the public, the facilitation of movement for people generally, and a full and complete respect for the freedoms of assembly and expression. Steering crowds away from crush points ${ }^{20}$ may suggest a need for "buffer zones" that are larger than the need for security alone would dictate. ${ }^{21}$

4. Law enforcement: The apprehension of violent individuals or of vandals operating under cover of a crowd, whether politically motivated (for example, the black bloc) or otherwise (as at hockey celebrations), as well as riot control are proper law enforcement activities that may, predictably, be required when large events take place.

\section{Common Law Authority on Police Powers}

It is helpful to bear these distinct needs in mind when assessing the legal frameworks required by very large events. The policing provisions of the Foreign Missions Act speak only to the first - and then only in the context of international conferences. So too, the common law fails to sufficiently address these diverse needs. As a practical matter, it operates at a level of principle and generality that falls far short of codification. It is neither clear enough nor sufficiently precise to direct the zoning of city centres and the regulation of movement over extended territories and for extended periods of time. As Stribopoulos observes,

20 For the hazards of crushing, see eg John J Fruin, "The Causes and Prevention of Crowd Disasters" (paper delivered at the First International Conference for Crowd Safety, London, England, March 1993), revised for crowdsafe.com (January 2002), online: <www.crowdsafe.com/FruinCauses.pdf>; see also Health and Safety Executive, "Crown Management" (Government of the United Kingdom), online: <www.hse.gov.uk/eventsafety/crowd-management.htm>, which identifies the "hazards presented by a crowd" as including crushing ("between people" or "against fixed structures, such as barriers," "trampling underfoot," "surging, swaying or rushing," "aggressive behaviour," and "dangerous behaviour, such as climbing on equipment or throwing objects").

21 The creation of exclusion zones designed to shield dignitaries from awareness of protest would, however, be an improper interference with constitutionally protected freedoms. Commission for Public Complaints against the RCMP, Commission Interim Report Following a Public Hearing into the Complaints Regarding the Events That Took Place in Connection with Demonstrations during the Asia Pacific Economic Cooperation Conference in Vancouver, B.C., in November 1977 at the UBC Campus and Richmond Detachments of the RCMP (Ottawa: Commission for Public Complaints, RCMP, July 2001) [APEC Report]; Pue, "The Prime Minister's Police" supra note 11 at $178-180$. 
[t]he principal problem with allowing the common law to continue supplying the governing legal framework ... is that it provides few clear answers. On a practical level, this means that the police will continue to do what they perceive as necessary. ... But as the statistics from the G20 Summit in Toronto aptly demonstrate, there will in all likelihood be a great many arrests, comparatively few prosecutions, and even fewer trials. In short, true accountability remains illusory. $^{22}$

The infringement of the rights, freedoms, and liberties of those whose lives are disrupted by official actions, even though they keep well away from protests and, thus, never face the threat of arrest, are even less likely to be adjudicated.

In any event, the common law is mistrustful of official claims of authority. It does not confer plenary powers on police. Stated baldly, this is so obvious as to seem trite. Nonetheless, confusion has arisen in fact as a result of some Canadian officials misconstruing the doctrine of ancillary police powers rather badly. This doctrine holds that police are accorded certain powers under common law that are necessarily ancillary to their ordinary duties, including the preservation of the peace. "Preserving the peace" is a legal term of art and, although it sounds like it might encompass almost anything, that is not the case. Courts over the centuries have been cautious not to allow this general duty to serve as a backdoor through which unlimited official authority enters. The reductio ad absurdum serves as caution. Stretched too far, almost any conduct, no matter how intrusive, could be defended as "ancillary" to the mission of preserving the peace and preventing crime. Free societies do not proceed in this fashion, and common law courts have not allowed this result. Bluntly, "[a] society that valued police efficiency and effectiveness above other values would be a police state." 23

$R v$ Knowlton is the leading Canadian authority on police restrictions of access to spaces such as streets, parks, and other places normally open to the public. ${ }^{24}$ In this case, the Supreme Court of Canada upheld the arrest of an individual who had refused police instructions to keep off a small portion of a public sidewalk. The area in question was immediately adjacent to the private property of Edmonton's Chateau Lacombe Hotel, which was then hosting Soviet Premier Alexey Kosygin. Security, of necessity, was tight. Kosygin's visit to Canada had not only provoked

22 Stribopoulos, supra note 9 at 115 . The contrary (that the common law is sufficient) view was recently stated, albeit in passing and without full consideration, by the esteemed Honorary R. Roy McMurtry, supra note 1. These observations are presented in the context of an analysis of the inadequacies of Ontario's PWPA, supra note 5, as a framework for policing significant events and without a full analysis of the common law powers of the police. For the latter, see Diab \& Pue, "The Gap in Canadian Police Powers", supra note 11. No other report on the G20 Summit addressed the question directly. Ontario's ombudsman focused on the actions of a provincial ministry, a report prepared for the Toronto Police Board focused primarily on the way the Police Board engaged with policing agencies, and the Office of the Independent Police Review Director focused mainly on a series of operational and tactical missteps by police. See sources cited in note 2, supra.

$23 \quad R v$ Clayton, 2007 SCC 32, [2007] 2 SCR 725 at para 59 [Clayton].

$24 \quad R v$ Knowlton, [1974] SCR 443, 22 DLR (3d) 755 (Fauteux CJ) [Knowlton]. 
protests but also violence. Bombs had been discovered near the Russian embassy, ${ }^{25}$ and Kosygin had been attacked while walking on Parliament Hill with Prime Minister Pierre Trudeau. Quite understandably, Edmonton police were on tenterhooks as they sought to avoid another international incident. Anxiety was heightened in a province where many traced their family origins to communist-ruled Eastern Europe. The question for the court was whether Knowlton's arrest in such circumstances - the hotel property, the adjoining sidewalk, the security concerns was lawful. The trial judge thought not:

[T]he police at the relevant time were not enforcing any provisions of the Criminal Code, or any bylaw or other law and that therefore they were not acting in the execution of their duty and that therefore the accused could not have been obstructing them and therefore not guilty of the offence of obstruction. Finding as I do there was not any law being enforced the accused could not have been found committing an offence so as to justify an arrest without a warrant and therefore the charge is dismissed. ${ }^{26}$

In the particular circumstances of the case, the Supreme Court of Canada took a different view but did not disagree with the fundamental principle: an unlawful interference with a person's liberty does not become lawful simply because done by police, whose authority derives only from statute or from clear common law authority. ${ }^{27}$

On the facts, it was clear that police, acting on the authority of the landowner, could lawfully have prevented entry to the Chateau Lacombe's property. It was the further step of restricting access to public land adjacent to the hotel that rendered the case difficult. On the facts of the case, the Supreme Court of Canada felt this action was permissible as a necessary consequence of constables' ancient common law duty to preserve the peace and prevent crime. ${ }^{28}$ The particular facts of Knowlton suggest its limits. ${ }^{29}$ It involved a de minimus intrusion on freedom of movement ancillary to the proper function of protecting private property, which was met, perhaps, by a brittle and unreasonable stance on Mr. Knowlton's part. At stake were a limited intrusion, a small physical space, and restrictions of short duration.

Since Knowlton, the common law doctrine of "ancillary police powers" has been held to authorize short investigative detentions or the search of persons, vehicles, or premises where necessary to preserve evidence, to ensure the safety of police officers, or to prevent the

25 "Metro Socred Candidate Held in Ottawa. Attack on Kosygin Shameful: PM", Globe and Mail (19 October 1971) at 1; "Kosygin Shaken Up in Ottawa Attack", Milwaukee Sentinel (19 October 1971) at 1.

26 As quoted in Knowlton, supra note 24 at 445.

27 Ibid at 446, citing Regina $v$ Waterfield, [1964] 1 QB 164 at 170.

28 This common law authority was given statutory expression in the Police Act, RSA 2000, c P-17, ss 38-41.

29 It is elementary legal method that the rule in a case (its ratio decidendi) is limited by the factual circumstances generating judicial statements. See eg ATH Smith, Glanville Williams: Learning the Law, $15^{\text {th }}$ ed (London: Sweet \& Maxwell, 2013) at 96: "[T]he ratio decidendi of a case can be defined as the material facts of the case plus the decision thereon." 
continuation of an offence. ${ }^{30}$ A need to respond quickly to unanticipated new or developing situations and inherent limitations of time and space are common features of such decisions. Construing the "ancillary" powers doctrine as having imported a general police power to seal off large public spaces, to search or detain large numbers without cause, and to do both for periods of days, however, would be taking Knowlton into new territory.

Two important cases illustrate the limits of ancillary police powers. In Dedman v The Queen, Justice Gerald Le Dain crafted a test to be applied prior to establishing new "ancillary" police powers. ${ }^{31}$ This test involved weighing:

1. whether the interference is necessary to carrying out a particular police duty; and

2. whether it is reasonable, having regard to
a. the nature of the liberty interfered with, and
b. the importance of the public purpose served by the interference.

On the facts in this case, a majority of the court upheld random traffic stops that had been implemented in order to reduce impaired driving. The particular police duty to which an ancillary power adhered was derived from a scheme of statutory regulation involving the licensing of both vehicles and drivers. The majority of the court viewed driving, not as one among many means of exercising ordinary freedoms of movement but as a licensed and highly regulated activity. That being the case, the seriousness of drunk driving and the "slight" infringement" associated with a brief traffic stop rendered this practice properly an "ancillary" police power. ${ }^{32}$ In other words, powers to detain briefly or to "search" are permissible under the doctrine where necessary to fulfill ("ancillary" to) a clearly established police function. Even then, the particular exercise of power must be reasonably proportionate to the threat presented by the specific harm. It should be noted that this is an additional requirement, not the elevation of a "reasonableness test" in lieu of the other components.

A similar approach was adopted in Cloutier $v$ Langlois, which considered the lawfulness of a "frisk search" conducted at the time of arrest. ${ }^{33}$ Again, a rigorous two-stage test was applied. The Supreme Court of Canada asked, first, whether either a statute or the common law imposes a particular duty on peace officers. The duty must be "clearly identified" and historically recognized by the courts. Only if it is thus established does the second question come into play: was the action necessary to the fulfillment of the duty? ${ }^{34}$ Only such powers as are necessary to the performance of well-established police duties are to be inferred. Ancillary powers are tethered tightly to explicit statutory duties and to specific, well-established, common law

\footnotetext{
$30 \quad R v$ Mann, 2004 SCC 52, rev'g 2002 MBCA 121 [Mann]; $R v$ Greaves, 2004 BCCA 484 [Greaves]; Dedman v The Queen, [1985] 2 SCR 2 [Dedman].

Ibid.

Ibid at para 69.

Cloutier v Langlois, [1990] 1 SCR 158 [Cloutier].

Ibid at $182-183$.
} 
duties. ${ }^{35}$ Constables' general obligations to preserve the peace or prevent crime cannot provide a sufficient hook on which to hang ancillary powers, for that would generate a novel and dangerous relationship between police, the law, and the community at large. Any such approach would de-link police powers from legislative conferral. As Chief Justice Brian Dickson observed,

[a] police officer is not empowered to execute his or her duty by unlawful means. The public interest in law enforcement cannot be allowed to override the fundamental principle that all public officials, including the police, are subject to the rule of law. To find that arbitrary police action is justified simply because it is directed at the fulfilment of police duties would be to sanction a dangerous exception to the supremacy of law. It is the function of the legislature, not the courts, to authorize arbitrary police action that would otherwise be unlawful as a violation of rights traditionally protected at common law. ${ }^{36}$

As in Dedman, the Court required also that exercises of "ancillary" police power be reasonably calibrated to the nature of the liberty interfered with, taking account of all competing public interests. In short, for a lawful ancillary police power to be asserted it must be both necessary and reasonably calibrated and appended to a clear and particular police duty. No short-cut allows any of these components to be skipped over or diluted.

The measures commonly employed at large gatherings differ fundamentally. Closure of large public spaces for extended periods of time is quite unlike anything that has been upheld under the ancillary powers doctrine. So too, there is no authoritative ruling at common law upholding the notion that police may subject large numbers of people to surveillance and search without cause, erect fences around private property so as to inhibit access, or issue passes permitting only some people to move freely through public spaces. Figueiras $v$ Toronto (Police Services Board), a case arising from an incident taking place during the G20 meetings in Toronto, confirms that lawful police powers must be closely tied to a statutory or regulatory grant of authority and, correspondingly, that claims to authority grounded on the "ancillary" powers notion are strictly confined. $^{37}$

\section{Special Police Powers at Inter-Governmental Meetings}

Let us return to look more carefully at the federal Foreign Missions Act since it speaks to the four distinct sorts of needs that arise. The Act provides only a partial bridge over the gaps in

35 Cloutier was misapplied in interlocutory proceedings in Tremblay c Québec (Procureur général) [2001] JQ no 1504 [Tremblay]. See Diab \& Pue, "The Gap in Canadian Police Powers", supra note 11 at 93-97, and discussion below. The Tremblay decision is also discussed in Pue, "Trespass and Expressive Rights", supra note 11 at 8-21. An English translation of the judgment is produced as an appendix to that article.

36 Dedman, supra note 30 at para 25. Though dissenting in application to the facts, the principles stated here are in accord with the majority ruling (at 26).

37 Figueiras v Toronto (Police Services Board), 2015 ONCA 208, especially, paras 61 and 109 (lack of statutory authority; parameters of common law police powers), 79 and 128 (common law right to liberty), 91 (limits of powers ancillary to obligation to preserve the peace) (per Rouleau JA, Rensburg JA, and Pardu JA concurring). 
common law police authority. It confers power on the Royal Canadian Mounted Police (RCMP) to use security perimeters in order to protect international conferences but only to the extent necessary "to ensure the security for the proper functioning of any intergovernmental conference in which two or more states participate." 38

The statute was passed in the wake of an embarrassing debacle at the Quebec City Summit of the Americas Conference in $2001 .^{39}$ Policing measures taken there provoked a near-miss legal challenge that revealed their insecure legal foundation. In Tremblay c Québec, the applicant challenged restrictions on his freedom arising from the creation of an extensive exclusion zone. His application for injunctive relief was heard immediately before the summit's start. At that late date, the granting of an injunction would have profoundly disrupted police and security arrangements, likely derailing the meetings entirely. Hearing the issue in those circumstances, a court of first instance ruled that extensive security perimeters, searches, and "pass systems" were permissible even without statutory authority. The ruling skipped lightly over the source of police authority, rather taking for granted that it flowed somehow from the common law. Despite the marked divergence from the Canadian norm, there was no careful analysis of precedent regarding ancillary powers. The learned judge's decision centred instead on the secondary matter of whether the exercise of such a power (assuming it to have been prescribed by law) would be justifiable under the Canadian Charter of Rights and Freedoms. ${ }^{40}$ The judge thought so, though the circumstances of course precluded a full hearing even on that matter.

Despite the final decision, the case illustrated the insecurity of RCMP practices as well as hinting at awkward questions of jurisdiction between federal and provincial policing authorities. The government of the day responded by passing amendments to the Foreign Missions Act, which accorded "primary responsibility" to the RCMP to ensure the security and proper functioning of certain inter-governmental conferences. ${ }^{41}$ Its authorization of "controlling, limiting, or prohibiting access to any area to the extent and in a manner that is reasonable in the circumstances [section 10.1(2)]" confers seemingly sweeping powers, without further elaboration. ${ }^{42}$ Section 10.1(2) combines brevity with vagueness.

Not surprisingly, policing authorities, provincial and municipal governments, and citizens alike have been left uncertain as to the extent of RCMP authority, the manner in which it should be exercised, and the division of responsibilities between federal and provincially constituted police forces. There is no statutory guidance indicating the scope of the powers conferred ("appropriate measures") or providing a framework by which to balance the needs of security against ordinary freedoms ("in a manner that is reasonable in the circumstances"). There is nothing to guide police as to how extensive their security perimeters should be, how long they can be established for, or what the requirements may be respecting notice to affected persons. No criteria are established regarding who should be permitted to cross security perimeters nor the

Foreign Missions Act, supra note 5.

Tremblay, supra note 35.

Canadian Charter of Rights and Freedoms, Part I of the Constitution Act, 1982, being Schedule B to the Canada Act 1982 (UK), 1982, c 11 [Charter].

$41 \quad$ Foreign Missions Act, supra note 5.

42 Ibid. 
process by which this critical decision should be made. Nothing is said about how to manage interference with private property and its enjoyment when homes or businesses are caught behind security fences. There is no indication as to what considerations need to be taken into account, none as to who should be consulted (if anyone) as part of the decision-making process. ${ }^{43}$ The legislation establishes neither high-order principles by which to drive decisions nor any more specific criteria directing implementation. It is entirely opaque as to the other things (aside from controlling access to public space) that fall within the general grant of power to implement "appropriate" measures. The statute gives no indication as to where federal jurisdiction ends and where the ordinary provincial jurisdiction remains in place. In short, the statute entirely fails to provide a code for the policing of major events. Its language is too general and its terms too vague to provide practical guidance. ${ }^{44}$

\section{Policing Geographies: The G20's Exclusion Zones}

The obvious failings of the G20 organization in Toronto provoked a number of official reviews, which together provide unique insight into how the existing legal frameworks operate in the real world. A number of challenges were apparent as police forces navigated between federal and provincial jurisdiction, between police and civil authority, and in the nebula between the common law and the Foreign Missions Act. The geography of crowd management and security put in place for the Toronto meetings mapped loosely onto the different types of need previously identified. Four policing zones were created.

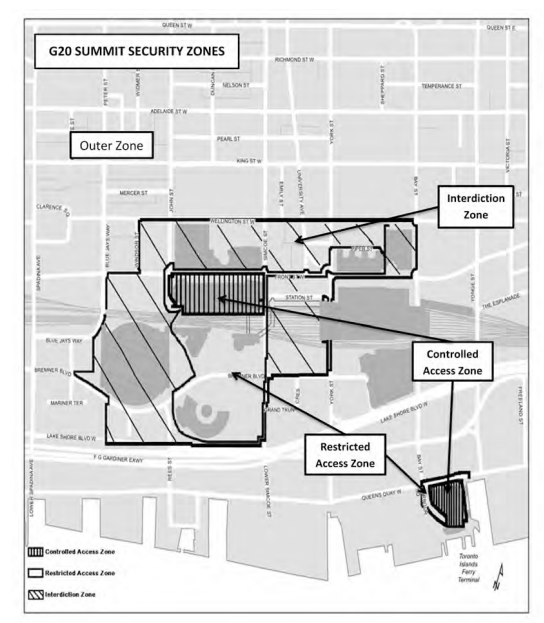

Figure 1: Honorable John W. Morden, Independent Civilian Review into Matters Relating to the G20 Summit, June 2012, at p 130.

43 One effect of Vancouver's municipal Bylaw 9962, supra note 5, passed prior to the Olympics was to force the RCMP to work with the city and to give Vancouver's city police a degree of authority vis-à-vis the RCMP that they otherwise would have lacked.

44 The question whether such a provision would survive review under Canada's constitutional constraints on statutory vagueness is beyond the point. See $R v$ Nova Scotia Pharmaceutical Society, [1992] 2 SCR 606, for a statement of Canadian law on constitutional vagueness and the brilliant analysis of this and related constitutional doctrines provided by Marc Ribeiro, Limiting Arbitrary Power: The Vagueness Doctrine in Canadian Constitutional Law (Vancouver: UBC Press, 2004). 
The zones were accorded different levels of security and also represented divisions in authority between Canada's federal police (event "security') and the City of Toronto police (urban policing more generally). Their delineation illuminates the intersection of the common law and statutory authority of police forces.

A "controlled access zone" formed the highest security area. ${ }^{45}$ Its boundaries were determined with the security of delegates and the functioning of the meetings as the driving concerns. It fell squarely within the ambit of Foreign Missions Act's policing provisions, which authorized the security perimeter and accorded primacy to the RCMP. Even without the act, the creation of this zone would likely have been lawful as an exercise of the "ancillary" police power. The RCMP's fence tightly circumscribed private venues in a fashion closely analogous to the Knowlton case. Assuming only that the owners of the convention centre and the hotel wished to have their property sealed off from the public in this way and that any ancillary enclosure of public spaces was minimal, no one would have ground for complaint. ${ }^{46}$

The second and much larger "restricted access zone" extended roughly 500 metres from north to south and 300 metres on its east-west axis. ${ }^{47}$ Private businesses, public thoroughfares, and a significant amount of public space were put behind police barricades. In this area, the property rights of a single landowner could not provide a hook on which to hang a Knowlton-like "ancillary" power. Here, the grant of police powers under the Foreign Missions Act comes into play, provided that the creation of the zone was necessary "to ensure the security for the proper functioning" of an inter-governmental conference, "appropriate," "reasonable in the circumstances," and defensible under constitutional protections, including (but not limited to) those of the Charter. ${ }^{48}$ Assuming that its boundaries enclosed the minimum area consistent with the security and "proper functioning" of the conference, it too was both authorized by law and constitutionally appropriate. Nonetheless, the legislative framework leaves much uncertain. We do not in fact know, even in general terms, the criteria that the police would apply in establishing this sort of zone, in deciding how to operate it, or in determining when to grant or refuse entry.

45 "The Controlled Access Zone: This area encompassed the MTCC [Metro Toronto Convention Centre] where the G20 Summit meetings were held and certain hotels where world leaders stayed during the event. The Controlled Access Zone was surrounded by a fence on the east, west, and north sides, with cameras monitoring the railway tracks that were located on the south side. Valid credentials were required to enter the Controlled Access Zone. The RCMP maintained sole responsibility for security and credentialing with respect to the Controlled Access Zone." TPSB Review, supra note 1 at 127-129. For other descriptions of the zones, see OIPRD Report, supra note 1 at 25.

46 The courts generally extend wide latitude to owners of private property in determining who can enter their premises and for what purposes. See eg Harrison v Carswell, [1976] 2 SCR 200, and the helpful discussion of this case provided in Philip Girard \& Jim Phillips, "A Certain 'Malaise': Harrison v. Carswell, Shopping Centre Picketing, and the Limits of the Post-war Settlement" in Judy Fudge \& Eric Tucker, eds, Work on Trial: Canadian Labour Law Struggles (Toronto: Irwin Law, 2010) 249 at 249-280.

47 "The Restricted Access Zone: This was a slightly larger area that surrounded the Controlled Access Zone and included the rest of the hotels where the world leaders stayed during the event. The Restricted Access Zone was surrounded by its own fence. The RCMP maintained sole responsibility for security and policing within the Restricted Access Zone." TPSB Review, supra note 1 at 127-129. This zone ran north to south from Front Street to Lakeshore Boulevard and west from John Street to Simcoe Street in the east.

48 Charter, supra note 40. 
Moreover, there is no statutory provision addressing the needs of those adversely affected or setting out remedies for them. ${ }^{49}$

A third area, referred to as the "interdiction zone" was established by the Toronto police. It covered a larger portion of downtown Toronto, enclosing private residences, businesses, streets, and other public spaces. ${ }^{50}$ This makes it unlike either the closure of private space with the consent of a single property owner (such as Edmonton's Chateau Lacombe Hotel or the University of British Columbia's Vancouver campus or the Metro Toronto Convention Centre) or restrictions that affect only access to public spaces. Its delineation had adverse effects on the rights of movement, expression, and assembly for people in general as well as on the privileges and rights of owners of private property. Such consequences may well fall within the scope of the Foreign Missions Act's authorization, but that would be so only to the extent required to protect the security and function of the conference itself. Both its extent and the initial assignment of responsibility to the Toronto Police Service suggest that the "interdiction zone" was not required for the "security" or "functioning" of the meeting, strictly construed, making the Foreign Missions Act unavailable as a source of police authority.

The area beyond the perimeter fences was referred to by police as the "outer zone." Policed by the Toronto Police Service, it "encompassed various areas, including Queen's Park [the provincial legislature area], consulates, financial sites, and Toronto Police Service Headquarters." Thus, "geographically, the Interdiction Zone fence line became an important boundary between Toronto and high-security areas in which Internationally Protected Persons [IPPs] or other Summit delegates were located.",51

49 The federal government set up a process following the G20 by which affected businesses in Toronto could seek compensation for disruptions suffered. See Postmedia News, "Ottawa Agrees to Pay Businesses Nearly \$2M in G8/G20 Compensation”, National Post (15 June 2011), online: <www.nationalpost.com>. According to this report, "[a]s it has done following international summits in the past, last year the Foreign Affairs Department set up an ex-gratia payment program to compensate local businesses who lost money because of the security measures that surrounded the G8 and G20 summits." The government had set aside \$13.45-million for compensation, but received only "411 claims totalling \$11.7-million - \$11-million from Toronto businesses affected by the G20 and \$700,000 from Muskoka-area businesses affected by the G8” by the deadline for applications.

"The Interdiction Zone: This area extended in all directions beyond the Restricted Access Zone perimeter fence and surrounded the Restricted Access Zone and Controlled Access Zone. ... The Interdiction Zone was surrounded by approximately 3.8 kilometres of chain link fencing that, when atop concrete barriers, had a height of almost ten feet. Toronto residents who obtained security approval before the G20 Summit would have to show their approval document at a gate on the Interdiction Zone fence in order to be permitted entry into this zone. The Interdiction Zone also included the PATH system in Toronto that runs underground and connects certain buildings in the downtown core. The Toronto Police Service was responsible for the security and credentialing at the Interdiction Zone fence.” The following are within the boundaries of the interdiction zone as reported in the TPSB Review, supra note 1: condominiums at 30 Grand Trunk Crescent (just off Bremner Blvd.) and two condominium buildings at the "Maple Leaf Square Condominiums" on York Street south of Bremner Blvd.

51 TPSB Review, supra note 1 at 129. 


\section{B. Establishing Legal Foundations at the G20 Summit and Vancouver Olympics}

Since neither the common law nor the Foreign Missions Act provide authority for the full repertoire of policing measures needed, ad hoc arrangements were pieced together in both Toronto and Vancouver. In one case, a long-forgotten statute (itself surprisingly vague) was resurrected to provide lawful authority for police barricades beyond the "controlled access" and "restricted access" zones; in the other, a city bylaw filled the void.

\section{G20 Summit: Inter-Agency Confusion Regarding Police Powers}

Confusion arose at the G20 Summit as city police and the RCMP navigated the borderlands between federal and provincial jurisdiction. While the Foreign Missions Act gave the RCMP "primary responsibility" over security for the conference, ${ }^{52}$ Toronto's police retained authority over most of the city. Straight-forward though that may seem, devils lurk in the details. Practical matters such as exactly how, when, and where the RCMP or Toronto Police Service's command structures would prevail proved a source of continuing confusion. One review found that "[d]uring the planning process, the Toronto Police Service struggled to understand its role, planning responsibilities and the legal authority on which it would act in respect of certain G20 Summit issues." ${ }^{, 53}$ Although Ontario's Provincial Police [OPP] believed their exclusion zone around meetings in Huntsville was authorized by common law, ${ }^{54}$ Toronto's Police Service remained uncertain of its authority to construct any security perimeter other than those flowing from the RCMP's statutory authority. ${ }^{55}$

Several efforts were made to redress this lacuna. Under section 10.1(4) of the Foreign Missions Act, the federal government is authorized to enter into an arrangement with a provincial government for the provision of security at inter-governmental conferences. ${ }^{56}$ Ontario's Ministry of Community Safety sought an "arrangement" with the federal government in the hope that this would extend the act's powers to local and regional police forces. ${ }^{57}$ Both the Toronto Police Service and the City of Toronto were simultaneously engaged in discussions with the federal ministry and with the RCMP toward the same end. ${ }^{58}$ The federal government balked, Federal Deputy Minister of Public Safety William V. Baker telling his provincial counterpart that such an arrangement was "not required for the Summits as it would not grant further authorities to local police of jurisdiction" [sic]. He had also expressed his belief that "the current suite of

52 Foreign Missions Act, supra note 5; see also Criminal Code, RSC 1985, c C-46, s 2 [Criminal Code]:

"[I]nternationally protected persons."

53 TPSB Review, supra note 1 at 124.

54 Ibid. The security perimeter the OPP erected at Huntsville was eight kilometres long and fenced in a "few hundred" residents. People who lived or worked within the zone were to receive accreditation passes five days before the G8 began. See Jennifer Yang, "G8 Brings Trepidation in Huntsville", Toronto Star (21 May 2010), online: <www.thestar.com>. The OPP reported subsequently that its "Interdiction Zone ... encompassed an area of approximately fourteen square kilometres, and included nearly 1000 residents." OPP, supra note 1 at 6 . Julio Fantino was then Ontario provincial police commissioner.

55 OIPRD Report, supra note 1 at 28.

56 Foreign Missions Act, supra note 5, s 10.1(4).

57 See McMurtry, supra note 1 at Appendix 6.

58 Ombudsman's Report, supra note 1 at 51. 
powers and authorities $[$ sic] that peace officers possess at common law or by virtue of any other federal or provincial Act or regulation were sufficient." ${ }^{, 59}$ Although mistaken regarding the common law powers of the OPP, the federal ministry was probably correct that the "arrangements" contemplated by the Foreign Missions Act legislation were unavailable for the purposes sought. The view that the broad powers to employ the "appropriate measures" contemplated in section 10.1(2) were exclusive to the RCMP, and could not be delegated to other forces, is plausible. Section 10.1(4) allows for "arrangements" only "to facilitate consultation and cooperation," while section 10.1(2) explicitly confers on the RCMP the power to take "appropriate measures." 60

The federal government's misunderstanding of the general law of police powers was shared by senior RCMP officials (no surprise as they have no way of obtaining independent legal advice). Commissioner Alphonse MacNeil mistakenly thought that "common law provisions and general police practices would have supported the [Toronto Police Service] in the delivery of their security operation in Toronto." 61 The RCMP also declined to designate Toronto police officers as special constables under the Royal Canadian Mounted Police Act in order to bring them under the Foreign Missions Act. ${ }^{62}$ However, even this would have left the critical question of the spatial extent of the special federal policing power unresolved, for not everything turns on the colour of the uniform worn. How deep into an urban area and how far away from delegates or conference facilities the federal power extends is unclear. Whether this power is exercised directly by regular RCMP officers or by special constables is a second-order question.

The legal geography of public order policing raises puzzling questions about the G20 Summit zones. If the international conference triggered a need for the most massive security perimeters encompassing the interdiction, restricted access, and controlled access zones, in order "to ensure the security for the proper functioning" of the G20 Summits, the RCMP should have created the larger security perimeter directly and under their own command. In this case, there would have been no need to rely upon patched-together arrangements with local authorities, whether by means of the appointment of special constables or otherwise. If the RCMP simply needed more personnel to guard their security perimeters, the appointment of city police as special constables would likely have done the trick. However, if the larger security perimeter was not necessary for the purposes set out in the statute, as seems likely (as opposed to, say, being needed to manage crowds or traffic safely or in order to facilitate protests that were unlikely to disrupt the conference), then reliance upon the Foreign Missions Act's precisely limited powers would have

59 McMurtry, supra note 1 at Appendix 7.

60 The section in full reads: "For the purpose of carrying out its responsibility under subsection (1) [i.e., primary responsibility for conference security], the Royal Canadian Mounted Police may take appropriate measures, including controlling, limiting or prohibiting access to any area to the extent and in a manner that is reasonable in the circumstances." The Ontario Ombudsman's Report observes that the federal act does not and cannot confer police powers upon provincially constituted police officers and reports that federal lawyers took the view that no "arrangement" entered into with a province could have this effect. Ombudsman's Report, supra note 1 at 50-51, para 117.

61 OIPRD Report, supra note 1 at 28.

62 Ibid. Special constables can be appointed under section 7(1) of the Royal Canadian Mounted Police Act, RSC 1985, c R-10 [RCMP Act]. 
been improper. The Act's wording focuses on the safety of delegates at a conference, not on the regular provincial and municipal responsibilities to ensure traffic flows and the safety and wellbeing of those on adjacent or distant city streets.

Officials at the provincial Ministry of Community Safety, the City of Toronto, and the Toronto Police Service actively sought other possible sources of legislative authority. ${ }^{63}$ Chief Bill Blair explained that the intention was to seek authority beyond that available under the Foreign Missions Act. ${ }^{64}$ A lawyer at the Ministry of Community Safety proposed filling the gap by means of Ontario's $P W P A{ }^{65}$ Lawful authority for an exclusion zone could be created under the act by designating the proposed area - streets, buildings, and land - "public works." ${ }^{\circ 6}$ Passed as an emergency measure at the start of the Second World War, the PWPA authorized police to stop anyone from attempting to enter a public work, to demand proof of identity, and to carry out searches without cause.$^{67}$ It gave police officers unfettered discretion to refuse entry and also to use necessary force. ${ }^{68}$ However, it went even further. In the case of a dispute over the boundaries of a public work, an officer's sworn testimony on the point was to be taken as conclusive evidence. ${ }^{69}$ The act made it an offence to refuse to comply with a request or direction made under it and put the onus on the accused to establish lawful excuse. ${ }^{70}$

On the advice of counsel for the City of Toronto and the Toronto Police Service, Chief Blair asked the ministry to enact a regulation designating the boundaries of the (Toronto Police Service's) interdiction zone as a "public work." ${ }^{.71}$ Chief Blair sought the designation in order to buttress police authority for the creation of an exclusion zone and for the associated powers of detention and search on behalf of the Toronto Police Service and the Integrated Security Unit [ISU] generally. ${ }^{72}$ The OPP, RCMP, and Public Safety Canada were aware of the request. ${ }^{73}$ His request was made on 12 May, the regulation invoked on 3 June, filed with the registrar on 14 June, and posted on the province's "e-laws" website on 16 June, just ten days before the conference was to begin. ${ }^{74}$ This website is not widely read (to say the least). In what proved a stunning misstep, the provincial ministry decided to be "low-key and reactive" in invoking the law, rather than actively seeking to inform the public about it. ${ }^{75}$

\footnotetext{
TPSB Review, supra note 1 at 287.

Ibid.

65 PWPA, supra note 5 at 14; TPSB Review, supra note 1 at 288 (the email described the act as "the legislation that allows for control of access to public areas - buildings and the like").

66 TPSB Review, supra note 1; Ombudsman's Report, supra note 1.

67 PWPA, supra note 5; for further context on the Act, see OIPRD Report, supra note 1 at 28.

68 PWPA, supra note 5, s 3(c).

69 Ibid, $\mathrm{s} 4$.

$70 \quad$ Ibid, s 5.

71 Ombudsman's Report, supra note 1 at 52. With respect to the timing of the pursuit of legislative support, the TPSB Review, supra note 1 at 287: "[T]he PWPA was being considered before the Government of Canada's letter was received by the Toronto Police Service on June 11, 2010 and was resorted to not simply because the federal government declined to enter into an FMIOA arrangement."

72 McMurtry, supra note 1 at Appendix 3; see also at 2.

73 Ombudsman's Report, supra note 1 at 57.

74 Ibid at 64.

75 Ibid at 57.
} 
The result was to bring into force coercive law that was in effect kept secret from members of the public who were expected to obey it. This elementary blunder spawned confusion among officials, attached the taint of secret laws to the effort to ensure that police acted with lawful authority, and inhibited efforts to train police officers properly in its application. Ontario's ombudsman concluded that responsibility for failure to inform the public about the invocation of the wartime legislation lay mostly with the province. It was surprising, he thought, that although the invocation of the PWPA "affected a large segment of downtown Toronto, the Ministry made no attempt to consult city officials about the impact of the public works designation." ${ }^{, 76}$ The same point registers, a fortiori, with respect to the exercise of similar police power employed in identical fashion without the cover of statute. Civil authority was diminished as police agencies took charge.

Surprisingly, Toronto's chief of police remained unaware of the new regulations until the day before the G20 Summit was to begin (25 June). Like almost everyone else, he learned about it through the media after the first arrest for violation of the regulations. ${ }^{77}$ Nobody had thought to inform Chief Blair that the regulation had come into effect, and he learned only that morning that some of his officers were acting under its authority, as they understood it. ${ }^{78}$ A worst case scenario emerged as police officers exercised authority they did not understand: some exceeded the letter of the law as well as the intent of those who had requested and enacted the regulation. It was a mess.

Toronto's media found it exciting that a "war time" regulation was in play and focused attention on the scope and validity of powers exercised under the regulations. Chief Blair compounded confusion by mistakenly asserting that powers to search and question under the $P W P A$ extended five metres outward from the interdiction zone's fence. ${ }^{79}$ Although the chief subsequently sent clarification to officers, ${ }^{80}$ no public correction was issued. ${ }^{81}$ Communications failed within the force, and "some officers continued to apply the Act well beyond the perimeter even after the scope of Regulation 233/10 had been clarified." ${ }^{, 82}$ At a post-G20 Summit press conference, Blair admitted there was not in fact a five-metre rule but explained that he "wanted to keep the criminals out."

\footnotetext{
Ibid at 62, para 155.

Ombudsman's Report, supra note 1; OIPRD Report, supra note 1 at 88.

Ombudsman's Report, supra note 1, at 72 (official notification from the minister had been received on 15 June). In any event, front line police officers were acting as if they enjoyed legal authority equivalent to that conveyed under the regulations).

$79 \quad$ Ibid at 67.

80 Ibid at 68 . Yet some in the ministry were also caught in the fog. As the ombudsman notes, "[w]hile the regulation was intended to provide "clarity," we found that Ministry officials did not share a uniform understanding of what it actually accomplished. Some were under the impression that the regulation designated the entire exterior security fence as the "public work," while others indicated that it was the whole area within the fence, and still others explained that it pertained only to a few specific places in the security perimeter which would not otherwise have been subject to the Act" (at 59).

$81 \quad$ Ibid at 71 .

82 Ibid at 72. Blair subsequently explained his failure to make a public correction on the grounds that he "wanted to keep the criminals out" (at 88).
} 
In a post-event Review of the Public Works Protection Act, which was prepared for the Ministry of Community Safety and Correctional Services, former Ontario Chief Justice Roy McMurtry concluded that the PWPA was constitutionally doubtful. ${ }^{83}$ Its definition of "public work" was "extraordinarily broad," he said, raising "questions of overbreadth" and giving cause for concern "from a policy standpoint" (as well, one might think, as creating vulnerability for vagueness or overbreadth under sections 7 and 1 of the Charter). ${ }^{84} \mathrm{He}$ viewed a provision allowing officers to stop and question persons entering a public work, or on their "approach thereto" (section 3(a)), as vague to a point approaching unconstitutionality, raising the likelihood that any detention or search pursuant to this provision would be unlawful. ${ }^{85} \mathrm{He}$ considered the lack of clarity particularly troubling given the possibility of a prosecution under section $5 .{ }^{86}$ The fact that conviction leading to imprisonment could result from the application of a reverse onus was, McMurtry thought, a violation of section 11(d) (presumption of innocence) of the Charter, which was unlikely to be saved by application of the "rational connection test" under section $1 .{ }^{87}$ Curiously, given that a review of federal legislation was not within his terms of reference, McMurtry remarked positively on the similarly vague provisions of the Foreign Missions Act. ${ }^{88}$ The province's Public Works Act was repealed in its entirety in 2015 without new legislation being introduced to govern the exercise of police authority at large events not related to court proceedings or electricity-generating facilities. ${ }^{89}$

\section{A Loss of Transparency and Accountability}

In planning for the G20 Summit, agencies worked together behind the scenes in an ISU overseen by a Steering Committee under the leadership of the RCMP. ${ }^{90}$ Both transparency and accountability were compromised as matters of practical importance, including the extent, duration, and location of security perimeters, and the requirements for passage through them were determined in closed meetings without the benefit of statutory guidance. The public, who was expected to comply with expectations established by police in this way obtained only partial (sometimes false $^{91}$ ) information, often communicated late in the day. Invariably, some found

83 McMurtry, supra note 1.

84 Charter, supra note 40; McMurtry, supra note 1 at 18.

85 McMurtry, supra note 1 at 40. McMurtry seemed unperturbed by the even greater vagueness and uncertainty arising from measures taken by police without statutory authorization. His brief discussion of this point does not provide an analysis of the common law and its limits (at 23-26). See, however, Diab \& Pue, "The Gap in Canadian Police Powers", supra note 11; Pue, "Trespass and Expressive Rights", supra note 11; Stribopoulos, "The Rule of Law on Trial, supra note 9.

86 McMurtry, supra note 1 at 19.

87 Ibid at 44. Section 1 of the Charter, supra note 40 provides: "The Canadian Charter of Rights and Freedoms guarantees the rights and freedoms set out in it subject only to such reasonable limits prescribed by law as can be demonstrably justified in a free and democratic society." On the constitutional validity of the PWPA, see also Roach, supra note 19 at 67-69.

88 McMurtry, supra note 1 at 27-30.

89 Security for Courts, Electricity Generating Facilities and Nuclear Facilities Act, 2014, SO 2014, c 15, Schedule $1, \mathrm{~s} 1$.

90 See OIPRD Report, supra note 1 at $20-43$.

91 Ombudsman's Report, supra note 1 at 67. 
themselves unable to comply with police expectations that were not made known to them. Confusion extended to front-line police officers. The impact on residents, homeowners, business enterprises, people going about their daily work, as well as on lawful protesters, was significant. None had an opportunity to provide input; few were fully informed as to how they would be affected. No mechanism existed by which to remedy the harms suffered.

Failures of communication flowed both from the inadequate statutory frameworks and from the provincial ministry's unfortunate decision to conceal the invocation of the Public Works Act, amplifying problems. Many important matters were managed entirely within the police force's discretion: application procedures, eligibility, verification of identity, the databases that police would create or use, weaponry to be employed in summit policing, appeals of adverse decisions made by police officials, and the consequences of failure to apply (through inadvertence or otherwise) - all were determined by police as if they were mere office procedures. ${ }^{92}$

Media relations personnel from the various police agencies, working as the ISU's "G8-G20 Public Affairs Communications Team," were tasked with maintaining content for the ISU's website and liaising with interested stakeholders. ${ }^{93}$ Despite the obvious importance of road closures, the location of security perimeters, the availability of police "passes" for those wishing to traverse Toronto's streets, information about such matters was made available only late in the planning process, if at all. ${ }^{94}$

In summary, the extensive and in-depth official reviews of the G20 Summit events reveal much about the interpretation of law by the officials most directly charged with this task. It seems clear that federal authorities believe that the creation of security perimeters established by local police solely for the purpose of ensuring public safety and managing pedestrian and traffic flow in the vicinity of an international conference lies outside of the Foreign Missions Act's ambit. This view, almost certainly correct, casts in stark relief the absence of legislative authority for the perimeters that may be needed because an international conference is taking place but that are not essential to its functioning. The late date on which the public learns the location of policed perimeters means that tests of their legality before the courts come either at the very last moment as ex parte brinksmanship (as in Tremblay) or ex post facto, when the issue is moot. This timing very nearly inoculates against judicial review. Power exercised without legislative

92 See W. Pue, "Analysis of Police Provisions in Bill C 35: An Act to Amend the Foreign Missions and International Organizations Act," Testimony, House of Commons Standing Committee on Foreign Affairs and International Trade, Tuesday, 6 November 2001 (on file with the author). Such concerns were, indeed, raised in Parliament as the amendments went through. See eg House of Commons Debates, $37^{\text {th }}$ Parl, $1^{\text {st }}$ Sess, No 116 (21 November 2001) at 7397 (Francine Lalonde); House of Commons Debatesw, $37^{\text {th }}$ Parl, $1^{\text {st }}$ Sess, No 117 (22 November 2001) at 7416 (Svend Robinson).

93 CPC Report, supra note 1 at 23.

94 A "statement of concerns" published 21 May 2010 by the Canadian Civil Liberties Association suggests that by that point in time, the size of the zones had not been made public. "Protecting Civil Liberties and Human Rights at the G20: Statement of Concerns", online: $<$ http://ccla.org/wordpress/wp-content/uploads/2010/05/G20-

CCLA-Statement-of-Concerns.pdf> at 4. See also Canadian Civil Liberties Association, letter to Toronto Police Chief William Blair and RCMP Commissioner William Elliott (4 June 2010), both texts are found in the Appendix to "Breach of the Peace", supra note 1 at appendix; Siri Agrell, "Pass Will Get Locals Past Outer Security Perimeter for G20 Summit", Globe and Mail (30 April 2010), online: <www.globeandmail.com>. 
guidance, even as to the governing principles, and exercised most often without legislative authority, is more or less immunized from court challenge.

\section{Inter-Agency Policing at the Vancouver Olympics}

Vancouver's Olympics worked out very differently. As sporting events are not, on the face of it, "inter-governmental conferences," the Foreign Mission Act's police powers seem unavailable. Just as at international conferences, crowd and traffic management for very large numbers of people were needed at locations that were far enough from Olympic sites as to have no direct effect on security of events, athletes, or Olympic personnel. Things worked better in Vancouver, no doubt, partly because authorities had considerably longer to prepare. The importance of this fact can scarcely be overemphasized. Other material differences were at play too. Vancouver's geography is not Toronto's, the configuration of its public spaces is unlike those in the vicinity of Toronto's G20 Summit sites. Sporting events attract a different sort of protester than G20 Summits, and British Columbia may have fewer self-declared "anarchists" organized for the purpose of vandalism or worse. Toronto is part of a much larger conurbation than the lower mainland (the metropolitan Vancouver area) and nearer to many large population centres both in Canada and in the United States, making it easier for committed protesters or simple troublemakers to travel to the city from elsewhere. It may be that the police themselves imagined the two events in quite different ways. Moreover, the influence of foreign security forces on Canadian policing at meetings where heads of government from around the world are present can be immense, and we do not know how these conditioned what played out in Toronto. Nonetheless, the challenges of managing, policing, and ensuring the security of the Olympics were enormous. ${ }^{95}$ In Vancouver, the legal gaps were filled by a municipal bylaw.

The RCMP operates as a federal police force in British Columbia, just as it does elsewhere in Canada. In British Columbia, unlike Ontario, they also serve under contract as provincial police and, in many municipalities (though, critically, not Vancouver) as municipal police. ${ }^{96}$ Vancouver's Olympics bid and subsequent selection caused agreements to be entered into between the province and federal government, the organizing committees and municipalities, setting out the responsibilities of the parties, including those relating to police and security. ${ }^{97}$

95 No one involved in Olympic security can overlook the symbolic importance of the games and all will be mindful of terrorist attacks in 1972. See David Binder, "9 Israelis on Olympic Team Killed with 4 Arab Captors as Police Fight Band That Disrupted Munich Games", New York Times (6 September 1972), online:

$<$ www.nytimes.com $>$.

96 See Police Act, RSBC 1996, c 367, s 3; RCMP Act, supra note 62, s 20; Government of British Columbia, "Province of British Columbia Provincial Police Service Agreement" (April 1992), online:

$<$ www.pssg.gov.bc.ca/policeservices/shareddocs/police-agreement-provincial.pdf $>$. Some larger cities have their own municipal forces (such as Vancouver, Delta, or Abbottsford, but not Richmond, Surrey, Kelowna, or New Westminster, for example). The extent to which RCMP officers working at or near Olympic venues at the University of British Columbia, Richmond, or Whistler understood their differentiated roles as federal and municipal police officers is unclear; so too the manner in which their internal organizational structures navigated this terrain.

97 See eg Agreement between Canada, British Columbia, Vancouver, Whistler, the Canadian Olympic Committee, the Canadian Paralympic Committee, and the Vancouver 2010 Bid Corporation (14 November 2002), online: $<$ www.canada2010.gc.ca/role/gc/mpa/MPA-e.PDF> [Multi-Party Agreement]; 2010 Olympic Games and 
Canada and British Columbia were to provide their normal policing and security services, subject to cost-sharing arrangements. The RCMP would "(1) [take] the lead in forming an integrated police planning group, (2) appropriate federal security measures which in the opinion of Canada are necessary, and (3) ... cooperate with [many] Games parties on non-federal security matters." 98

Much of the detailed implementation was fleshed out subsequently between the RCMP and the Vancouver Police Department [VPD]. ${ }^{99}$ An ISU and other inter-agency mechanisms were created. A relatively clear demarcation of jurisdiction between the RCMP and the VPD ("nonfederal security matters") emerged early: the VPD would maintain jurisdiction over the city of Vancouver, while the RCMP would assume "lead authority" over the "games security area" (that is, venues and the spaces surrounding them). ${ }^{100}$ This directly tracked the responsibility of the federal government for international affairs and was analogous to the division of policing spaces at an international conference. In Vancouver, as in Toronto, the scope of police powers required elaboration. A legal foundation was needed to confer necessary authority on one or other police force, to clarify responsibility as between jurisdictions, and to ensure the safe and efficient movement of massive numbers of people facilitated by means that might include street closures, issuance of passes, and searches without cause.

As in Toronto, uncertainty as to the legal authority for crowd management measures was unacceptable. In stark contrast to Ontario's preference for secrecy, British Columbia addressed the matter in a clear and public fashion. The City of Vancouver sought amendment of its enabling legislation, the Vancouver Charter, to "add to or clarify Council's powers of regulation" with regard to the Winter Olympics. ${ }^{101}$ It asked for authority to pass bylaws providing for temporary street closures, the regulation of advertising and signage on streets and in parks, and relaxing building and zoning requirements. New powers were also requested to regulate signage on private property, including authority to remove graffiti or signs on limited notice. An increase in the maximum fine for a bylaw offence to $\$ 10,000$ was sought. ${ }^{102}$

The provincial government tabled Bill 13, the Miscellaneous Statutes Amendment Act in response, ${ }^{103}$ but Vancouver City Council enacted an omnibus "2010 Olympic and Paralympic

Paralympic Games Security Cost Sharing Memorandum of Agreement (8 December 2006), online:

$<$ www.canada2010.gc.ca/docs/moa-eng.pdf> [Cost Sharing Memorandum of Agreement].

98 Multi-Party Agreement, ibid at 34 (Part 2).

99 Cost Sharing Memorandum of Agreement, supra note 97.

1002010 Olympic and Paralympic Winter Games Security Agreement between Canada and British Columbia (21

January 2009), online: <www.fin.gov.bc.ca/reports/Ministers_MOA.pdf $>$.

101 Vancouver Charter, SBC 1953, c 55.

102 General Manager of Olympic and Paralympic Operations and Director of Legal Services, "2010 Olympic and Paralympic Winter Games: Vancouver Charter Amendment Proposals", City of Vancouver Administrative Report RTS No 7680, Van RIMS No 08-2000-20 (17 December 2008), online: <http://vancouver.ca/ctyclerk/cclerk/20090120/documents/a8.pdf >. The powers were granted in Bill 13, Miscellaneous Statutes Amendment Act, 2009, $1^{\text {st }}$ Sess, $39^{\text {th }}$ Leg, British Columbia, 2009 [Bill 13]. See also Bylaw no 9697 on 2010 Winter Games Sign Designation and Relaxation Bylaw (8 July 2008); Bylaw no 9908 on 2010 Olympic and Paralympic Winter Games Bylaw (23 July 2009), [Bylaw 9908]; Bylaw 9962, supra note 5.

103 Bill 13, ibid. 
Winter Games bylaw" before the bill passed. ${ }^{104}$ This would have authorized closure or restricted access to streets and other public spaces, ${ }^{105}$ the use of airport-style security checkpoints, ${ }^{106}$ warrantless searches of persons and belongings without "reasonable cause," surveillance, ${ }^{108}$ and restrictions on the use of signs, ${ }^{109}$ megaphones, ${ }^{110}$ and other methods of expression. ${ }^{111}$ Fines were set at $\$ 2,000$ for each offence and $\$ 50$ per day for continuing offences. ${ }^{112}$ An exception to the prohibition on signage that would have allowed any sign "that celebrates the 2010 Winter Games, and creates or enhances a festive environment and atmosphere" was widely viewed as tilting too far towards censorship. ${ }^{113}$

The city denied any intent to "impact on freedom of political expression or the right to lawful protest," 114 defending restrictions on non-celebratory signs as a necessary protection for Olympic advertising and sponsorship arrangements. ${ }^{115}$ Two private citizens who viewed the bylaw as ultra vires the city and a violation of sections 2 (freedom of expression) and 7 (life, liberty, and security of the person) of the Charter initiated a court challenge. ${ }^{116}$ They viewed the failure to specify the prohibited "advertising material" $" 117$ as a critical rights infringement and believed a provision authorizing the city manager to make additional rules was both overbroad and too vague. ${ }^{118}$ On the face of it, other provisions, including prohibitions on bringing sticks or megaphones into designated sites, vague prohibitions on the "interfer[ence] with the enjoyment" of others, and new authority for search without cause, erection of security fences, and

104 Passage of the bylaw prior to the enactment of Bill 13 raised obvious questions as to its lawfulness.

105 Bylaw 9908, supra note 102, ss 10, 4B, 4D. See also City of Vancouver, "Supports Item No 4, CS\&B Committee Agenda", Administrative Report (23 July 2009), online: <http://former.vancouver.ca/ctyclerk/cclerk/20090723/documents/csbu4.pdf>.

106 Bylaw 9908, supra note 102, s 4C(a).

107 Ibid, s 4C(c).

108 Ibid, s 4C(b).

109 Ibid, ss 4B(d), 8, 9, 10.1(8), 10.1(11)(b), 10.1(14)(a).

110 Ibid, s 4B(a)(iv).

111 Ibid, ss 4B(b), (d).

112 Ibid, ss 14.4-14.5.

113 Ibid, ss 1.2, 8.3.

114 General Manager of Olympic and Paralympic Operations, "2010 Winter Games Bylaw Regarding the Vancouver 2010 Olympic and Paralympic Winter Games", City of Vancouver Administrative Report RTS No 08199, Van RIMS No: 08-2000-20 (6 July 2009) at 3 and 6, online: <http://vancouver.ca/ctyclerk/cclerk/20090723/documents/csbu4.pdf $>$.

115 The bylaw's terms, however, did not preclude that possibility. British Columbia, Legislative Assembly, Hansard, $1^{\text {st }}$ Sess, $39^{\text {th }}$ Parl, Vol 4, No 7 (19 October 2009) at 1233 (Mike Farnworth): "[I]n the public out there, these particular sections of this particular bill are already referred to as the jackboot clause ... because it is so broad in its definition. ... That is exactly what is wrong - the fact that this is so broad and is so vague."

116 Charter, supra note 40; Shaw and Westergaard Thorpe $v$ City of Vancouver, Court File no S-097345, Statement of Claim, filed in the Supreme Court of British Columbia (7 October 2009), online: $<$ http://bccla.org/wpcontent/uploads/2012/03/2009-BCCLA-Letter-Shaw-Statement.pdf>.

117 Bylaw 9908, supra note 102, ss 4B(d), 10.1.

118 Ibid s 4D: "[T]he City Manager may make additional rules concerning city land, and may post those rules at the entrance to city land." 
surveillance measures) may also have been vulnerable as ultra vires a municipality or otherwise unconstitutional. $^{119}$

When Bill 13 came forward in the provincial legislature, ${ }^{120}$ debate centred on freedom of speech and on the ability to post signs at one's home without interference. ${ }^{121}$ Opposition members expressed concern about the motivations behind the bill and about vagueness, overbreadth, and lack of transparency. ${ }^{122}$ Passed unamended, the bill came into force on 29 October $2009 .{ }^{123}$ The new legislation clarified the city's jurisdiction. The city removed doubt as to vires and buttressed against Charter challenge by substituting a new version of its earlier bylaw on 3 December 2009. ${ }^{124}$ This covered much the same ground, imposing restrictions on commercial speech ${ }^{125}$ and authorizing closure of public areas and streets. ${ }^{126}$ Airport-style security checkpoints were authorized at entrances to "city live sites." 127 The new version permitted warrantless searches of persons and their belongings (that is, without "reasonable cause"), ${ }^{128}$ authorized surveillance, ${ }^{129}$ and restricted freedom of expression (including by means of signs, megaphones, or other means). ${ }^{130}$ Some of the rough edges of the previous iteration were buffed off. A prohibition on protest within a forty-block radius of downtown Vancouver was abandoned, ${ }^{131}$ and restrictions on signage were more precisely focused on commercial messages. ${ }^{132}$

The legal challenge was abandoned after these changes were made, ${ }^{133}$ with the result that the constitutionality of the bylaw was never tested in court. Nonetheless, the first requirement for the

119 Ibid ss. 4, 13.3(e). For further context surrounding the litigation, see Megan Stewart \& Linda Solomon, "BC Civil Liberties Association Files Suit against City of Vancouver for Olympics Speech Restriction Bylaw", Vancouver Observer (7 October 2009), online: <www.vancouverobserver.com>.

120 In particular, Bill 13, supra note 102, Part 9, which proposed an addition to the Municipalities Enabling and Validating Act (No. 3), SBC 2001, c 44, in addition to amendments to the Vancouver Charter, supra note 101.

121 British Columbia, Legislative Assembly, Hansard, $39^{\text {th }}$ Parl, $1^{\text {st }}$ Sess, Vol 5, No 4 (22 October 2009) at 14271430 [Hansard, No. 4]; British Columbia, Legislative Assembly, Hansard, $39^{\text {th }}$ Parl, $1^{\text {st }}$ Sess, Vol 5, No 3 (21 October 2009) at 1381-1397 [Hansard, No. 3].

122 Hansard, No. 3, ibid at 1385 (Leonard Krog).

123 Hansard, No. 4, supra note 121 at 1429. There is no record of consideration having been given to proceeding by means of provincial statute or regulation rather than bylaw and no consideration appears to have been given to the governance of Olympic sites outside of the city of Vancouver.

124 Bylaw 9962, supra note 5; Rod Mickleburgh, "Vancouver Dumps Bylaw Derided by Activists as 'Beijing 2.0"”, Globe and Mail (27 November 2009), online: <www.globeandmail.com>; and Bob Mackin, "Council Bows to Pressure", 24 Hours Vancouver (27 November 2009), online $<$ Vancouver.24hrs.ca $>$.

125 Bylaw 9962, supra note 5, s 10(7)-(9).

126 Ibid, $\mathrm{s} 10$.

127 Ibid, s 4B(a).

128 Ibid, $\mathrm{s} 4 \mathrm{~B}(\mathrm{c})$.

129 Ibid, s 4B(b).

130 Ibid, ss 4A(a)(ii), 4A(d), 8, 9, 10, 4A(iv), 4A(c)-(d).

131 Gery Bellett, “Anti-Games Activists Drop Suit over Bylaws Restricting Protests”, Vancouver Sun (26 January 2010), online: <www.vancouversun.com>.

132 See eg Bylaw 9962, supra note 5, s 10.

133 Bellett, supra note 131. Bellett notes that applicant Chris Shaw estimated 80 percent of their requests had been met; and David Eby, for the BC Civil Liberties Association, expressed the view that most contentious parts of the bylaw, limiting forms of protest in certain areas, had been rescinded. 
lawful exercise of powers by police - that it be "authorized by law" - was met. Moreover, no taint of "secrecy" attached to the bylaw. Amendments to the Vancouver Charter had gone through the ordinary legislative process, and each version of the city bylaw was passed in the normal way during regular Council meetings. The new laws and arrangements flowing from them were well known.

Other aspects of large-scale event planning went smoothly, and no arrests were made for contravention of the bylaw. Although the public at large had little direct input as to when or where street closures, checkpoints, and so on were put in place, those actions were determined by their elected representatives through the ordinary processes, and information was communicated to the widest possible public. Outside of Vancouver, closure of the main highway connecting Vancouver to Whistler (approximately 129 kilometres) and other road closures were brought about through the ordinary public processes of municipal councils and provincial ministries as appropriate. ${ }^{134}$ Throughout, Vancouver Organizing Committee "engaged with stakeholders on matters such as transportation planning," including collaboration with "government partners and industry via an Olympic and Paralympic Transportation Team [OPTT]."135

Over 900 surveillance cameras were used in Vancouver. ${ }^{136}$ The two "City Live" sites were fenced off and access filtered through airport-style security screening. ${ }^{137}$ Other places normally open to the public, such as the plaza containing the Olympic flame, were fenced off entirely. ${ }^{138} \mathrm{~A}$

134 See Motor Vehicle Act, RSBC 1996, c 318, ss 124, 197; Vancouver Charter, supra note 101, s 317 (authority to pass bylaws regulating traffic); and Transportation Act, SBC 2004 c 44, s 61 (allowing the minister to close highways temporarily). See also "Vancouver 2010 Candidate City", online: <www.olympic.org/Documents/Reports/EN/en_report_706.pdf $>$. The Olympic and Paralympic Transportation Team released the Host City Transportation Plan in three phases: the first phase was set out in March 2009 in the Vancouver Olympic Committee's "Sustainability Report 2009-10", online: <http://www.olympic.org/Docu-

ments/Games_Vancouver_2010/VANOC_Sustainability_Report-EN.pdf $>$ at 66; Phase 2 was released on 14 October 2009 in the form of information set out on a webpage hosted by Translink BC, online:

$<$ http://buzzer.translink.ca/index.php/2009/10/phase-two-of-the-2010-olympic-transportation-plan-releasedtoday/>; and phase 3, which was titled the "Travelsmart 2010 Update: Start Planning to Leave Vehicles Behind for 2010 Winter Games Opening and Closing Ceremonies," and outlined temporary street closures, was released in January 2010. (The site is no longer available, but its content was summarized in a Canada news wire posting on 12 January 2010, online: <www.newswire.ca/en/story/712299/travelsmart-2010-update-start-planning-toleave-vehicles-behind-for-2010-winter-games-opening-and-closing-ceremonies $>$ ).

135 Sustainability Report 2009-10, ibid at 15, 66. Although now removed, "Travelsmart 2010", ibid, and the Integrated Security Unit's site <www.v2010isu.com> were examples. See also Security Intelligence Review Committee, "Security at the Olympic Venues: What to Expect" (1 February 2010), online:

$<$ www.sirc.ca/news_view.cfm?id=33676>. Vancouver 2010 Integrated Security Unit, Twitter feed (8 June 2010-22 October 2010), online: <https://twitter.com/v2010isu>. Facebook, Groupe integré de la sécurité de Vancouver 2010, online: <www.facebook.com/pages/Groupe-intégré-de-la-sécurité-de-Vancouver2010/185197474367>; Canadian Broadcasting Corporation, "2010 Guide: Map of Venues, Celebrations, Pavilions, Free Events, Transit and Road Closures during the Vancouver 2010 Winter Olympic and Paralympic Games" (10 March 2010), online: <www.cbc.ca/bc/features/roadtothegames/features/olympic-venues-eventstransportation/>.

136 Molnar \& Snider, supra note 1.

137 Bylaw 9962, supra note 5, Schedule A.

138 Associated Press, "Better Views of Olympic Flame on the Way", NBC News (16 February 2010), online $<$ www.nbcnews.com>. Vancouver Organizing Committee's Renee Smith-Valade asserted that the Olympic 
number of Vancouver locations designated as "venues" were subjected to noise, sign, and other restrictions. ${ }^{139}$ Streets surrounding venues ("venue corridors") were closed to drivers. 140

There is always room for disagreement on particulars, such as the precise boundaries of security perimeters, each restriction on movement and assembly, the extent of video surveillance, the appropriateness of warrantless searches, and the restrictions on signage. Careful, detailed, and specific analysis of each measure and of each boundary on the ground would be required to determine their desirability, wisdom, and constitutionality. The substantial public interest in securing safety where very large numbers gather militates in favour of some such measures derived from proper provenance, authorized by law, carefully drafted, and enforced with integrity. Whatever failings might attach to the particular provisions, the process was public, visible, and pursued through the ordinary channels. In a city where the memory of the previous decade's Asia-Pacific Economic Cooperation affair was still strong, ${ }^{141}$ Vancouver's media were well informed on the issues and on official actions. The local activist community was relatively vocal, and an independent Civil Liberties Advisory Council published a report of recommendations. ${ }^{142}$

\section{CONCLUSIONS}

A side-by-side comparison of the two events shows that Vancouver got much "right" at the 2010 Olympics, just as much went wrong at Toronto's G20 Summit. Three conclusions can be drawn regarding legal arrangements for each event. First, the ongoing gap in the authority of police and civic officials with respect to implementing measures to manage very large events needs to be resolved. A significant legal lacuna lies in the space between the RCMP's security jurisdiction under the Foreign Missions Act, common law police powers, and the authority of local governments. The spatial reach, scale, and duration of major events distinguish them from other events, revealing a substantial fissure between the security perimeter provisions in this Act

flame was cordoned off on account of safety concerns about the cauldron itself and because it was located within the security perimeter for the international broadcast and press compound and the main media centre. Fencing was moved closer and modified so as to facilitate viewing of the Olympic flame following public complaints.

139 Bylaw 9962, supra note 5, ss 7.1, 8.3, 8.6, 8.9, 8.10, 8.12, Schedule B.

140 Ibid s 10.

141 See eg Richard Ericson \& Aaron Doyle, "Globalization and the Policing of Protest: The Case of APEC 1997" (1999) 50 Brit J Sociol 598 at 589-618; Karen Pearlston, "APEC Days at UBC: Student Protests and National Security in an Era of Trade Liberalization" in Gary Kinsman, Dieter K Buse \& Mercedes Steedman, eds, Whose National Security? Canadian State Surveillance and the Creation of Enemies (Toronto: Between the Lines, 2000) 278; Pue, Pepper in Our Eyes, supra note 11; Pue, "The Prime Minister's Police?" supra note 11; Pue, "Executive Accountability and the APEC Inquiry", supra note 11. For a discussion of the protests around the Olympics and their context, see Nicolien van Luijk, The 2010 Winter Olympic Games: (Re)Framing Protest (BPhED thesis, University of British Columbia, 2010) [unpublished].

142 Civil Liberties Advisory Council, "Civil Liberties and the 2010 Winter Olympics: Report of the Civil Liberties Advisory Committee" (December 2009), online: <www.abbotsfordtoday.ca/wp-content/uploads/2010/02/civilliberties-association-final_report.pdf $>$. 
and ordinarily ancillary police powers. The practical difficulties arising are all too apparent from the history of official efforts to navigate this no-man's land in the planning for the G20 meetings.

Second, the two events clarify that the categories of "security," "public order," and the right to protest are not exhaustive of what needs to be taken into account as officials plan, manage, and police very large events. Important considerations respecting traffic flow for vehicles and pedestrians, public safety, business continuity, enjoyment of property, and the rights of association, movement, and expression are not subsumed under the simpler notion of police authority. The mechanisms employed in balancing competing interests such as these resonate more closely with municipal government functions (such as zoning, land use regulation, management of public spaces, and traffic planning) than with ordinary policing functions.

Third, a comparison of the two events reveals much about the range of legal possibilities for managing large events. Outside of the skeletal provisions in the Foreign Missions Act, no Canadian legislature has yet grasped this nettle. ${ }^{143}$ Assuming past behaviour to be the most reliable predictor of future conduct, the greatest likelihood is that this resounding legislative silence will persist indefinitely. However likely that may be in fact, continuing to pretend either that police have plenary power or that there is no problem to be addressed would be unfortunate. ${ }^{144}$ Such an approach contradicts Canada's commitment to the rule of law and perpetuates practical problems of the sort encountered at the G20 Summit. Disorder on the streets and impossibly confused relationships among police forces and between them and civic or provincial government are the predictable outcomes. Equally clear, the secret invocation of statutes violates the very idea of legality and leads to disastrous consequences. While the attempt to underpin policing measures at the G20 was in itself a good thing, the decision to proceed secretly was probably the single biggest error made by officials. ${ }^{145}$

The counter-example of the Olympics demonstrates that a well-crafted municipal bylaw can do much to bring clarity to the planning and policing of major events. The visible conferral of legislative authority on an established and accountable law-making body (city council) created certain defined arrangements for the management and use of public space. A clear scope of authority emerged that was intelligible to police and public alike. Jurisdictional uncertainty was minimized. And, unlike Toronto, the municipality asserted itself as an important decision maker

143 We discount Quebec's ham-fisted Bill 78, supra note 18, which was more an effort to silence government critics than to provide a balanced approach to recurrent large event challenges. See Tu Thanh Ha \& Les Perreaux, "Student Protests: Anti-Protest Legislation Passes in Quebec", Globe and Mail (18 May 2012), online: $<$ www.globeandmail.com>.

144 Morden's thorough report prepared for the Toronto Police Service Board proposes a shift in the line between governance by the board and management by the chief of police (traditionally understood as laying on the boundary between "policy" and "operations") as a partial remedy to the problems encountered. We do not address that proposal directly. Though it does have the virtue of introducing a kind of public accountability and, perhaps, transparency, it cannot address the scope of lawful police powers (addressing only how they are used) nor resolve inter-jurisdictional confusion regarding the interface of federal and provincial policing authority. See TPSB Review, supra note 1.

145 Admittedly, there are some other serious contenders however, including the prime minister's decisions to host a conference with only four months lead time, the logistical planning that left Toronto with insufficient numbers of police officers present to protect G20 barricades and the city centre, the management of detention facilities, kettling large numbers, and so on. 
in event management within its jurisdiction while nonetheless respecting, as appropriate, the special expertise and knowledge of police and security agencies.

There are limitations to local bylaws, however. Most obviously, they are ill-suited to circumstances where the need for planning of large events spans local jurisdictions. A Vancouver bylaw had no effect, good or ill, outside of the city limits, just as no arrangements local to Toronto would have helped in neighbouring municipalities. ${ }^{146}$ Moreover, bylaws passed ad hoc for a particular event leave recurrent needs untended to. The bespoke approach requires frequent re-invention: hockey finals, football championships, political protests, fireworks displays, demonstrations, international sporting events, a prime minister's visit to a Board of Trade, international meetings, outdoor concerts, and major inter-governmental conferences occur with predictable regularity. Moreover, few municipalities will be able to navigate this tricky terrain successfully without the guidance of provincial legislation. The City of Vancouver's success was possible only because of its significant staff resources, legal expertise, planning prowess - and because it enjoyed the conferral of special powers by provincial statute. Other municipalities are unlikely to be able to focus these sorts of resources in a similar fashion. Even in Vancouver, an imperfect first iteration was improved only following an expensive and consuming court challenge brought by private citizens: good public policy need not turn on such vagaries.

The management of large-scale events necessarily impacts on the common law's cherished rights of assembly, expression (both also protected in the Charter and, within the federal sphere, by the Canadian Bill of Rights), enjoyment of property (also protected, federally, by the Canadian Bill of Rights), and freedom of movement. ${ }^{147}$ A continuing failure to strike the right balance does ongoing damage to the relations of police to the larger public. The passage of legislation establishing this balance while providing guidance to police and public alike regarding what to expect at the wide variety of events that characterize any healthy and free society can only be helpful. ${ }^{148}$

Within the federal sphere, there is room for improvement in the Foreign Missions Act. Its provisions are vague and incomplete. They leave the boundary between provincial and federal jurisdiction uncertain as well as failing to provide effective guidance to police forces or to the general public. ${ }^{149}$ Greater clarity should - and could - be provided to define the boundaries of federal police jurisdiction, define the types of measures federal police may employ, and outline the means by which they might employ them. Statutory guidance regarding the proper purpose, extent, and duration of exclusion zones would be helpful; so too the provision of a framework for advance notice of closures of public space, mechanisms for limiting access or issuing passes, and establishing lawful and calculable process by which to evaluate claims for compensation by

146 Policing at or near venues in Richmond, Whistler, on Cypress Mountain, at the University of British Columbia, or in the unincorporated area misleadingly known as the University Endowment Lands could not be affected by a City of Vancouver bylaw.

147 Charter, supra note 40, s 2. Canadian Bill of Rights, SC 1960, c 44

148 See Diab \& Pue, "The Gap in Canadian Police Powers", supra note 11 at 105-107, for overviews of the Public Order Act 1986 (UK), 1986, c 64; Criminal Justice and Public Order Act 1994 (UK), 1994, c 33; APEC Meeting (Police Powers) Act 2007 (New South Wales). See also the Regulation of Gathering Act, 1993, Republic of South Africa, No 205 of 1993.

149 See TPSB Review, supra note 1. 
those whose homes or businesses are blocked by police barriers. Comprehensive legislation would provide guidance to authorities with respect to stakeholder consultation and public communications. If expanded powers of detention and search are needed beyond the boundaries of conference and delegate accommodation sites, a statutory conferral and definition of the special powers is needed.

In sum, the lack of statutory frameworks to govern the management of large events conspires against their successful management. Legislative silence sews confusion among officials at all levels and leaves the roles of local governments, police forces, and senior governments unclear. All of this tilts towards the likelihood of operational dysfunction, poor public communications, and public distrust of the police. Alhough good law does not ensure good outcomes, avoiding these ills and ensuring the benefits of clarity for police and citizens alike is a good starting point. Beyond this, as the great jurist Lon Fuller has put it, "the desideratum of clarity represents one of the most essential ingredients of legality." legislators.

150 Lon Luvois Fuller, The Morality of Law (New Haven, CT: Yale University Press, 1969) at 63. 